\title{
Analisis Daya Dukung Kualitas Air Untuk Kesesuaian Wisata Di Pantai Karang Jahe, Rembang
}

\author{
Fitri Kurniawati, Ibnu Pratikto, Widianingsih Widianingsih \\ Departemen IImu Kelautan, Fakultas Perikanan dan IImu Kelautan, Universitas Diponegoro \\ Jl. Prof.H.Soedarto S.H, Tembalang,Semarang, Jawa Tengah 50275 Indonesia \\ *Corresponding author, e-mail : fitrika07@gmail.com
}

\begin{abstract}
ABSTRAK : Pantai Karang Jahe merupakan salah satu destinasi wisata baru yang mulai menjadi tujuan wisata di Jawa Tengah. Sebagai tempat wisata baru, Pantai Karang Jahe memerlukan pengembangan dalam upaya menarik wisatawan untuk berkunjung. Penelitian ini bertujuan untuk mengkaji kesesuaian dan daya dukung wisata serta mengkaji potensi daya tarik wisata Pantai Karang Jahe, Rembang, Jawa Tengah. Penelitian dilaksanakan pada bulan Januari-Februari 2019. Penelitian menggunakan metode survei dan penentuan lokasi dipilih dengan menggunakan metode purposive sampling.. Pada Penelitian ini dilakukan analisa Indek Kesesuaian Wisata (IKW) dan analisa Daya Dukung Kawasan (DKK). analisis data kesesuaian kawasan menggunakan rumus $\mathrm{IKW}=[\mathrm{Ni} / \mathrm{Nmaks}] \times 100 \%$ dan analisis daya dukung kawasan Bertdasarkan pengamatan diperoleh hasil bahwa nilai IKW untuk rekreasi pantai pada stasiun 1,2 dan 3 tergolong sangat sesuai (S1) dengan nilai 88,88\%; 91,94\%; 84,72\%. Nilai Daya Dukung Kawasan (DDK) yaitu kegiatan rekreasi pantai dengan luas $1200 \mathrm{~m}^{2}$ sebesar 96 orang/ hari, kegiatan berenang dengan luas $1100 \mathrm{~m}^{2}$ dapat menampung 88 orang/ hari, dan kegiatan bermain dengan luas $1000 \mathrm{~m}^{2}$ dapat menampung 80 orang/ hari. Berdasarkan hasil analisa IKW dan DDK dapat disimpulkan bahwa Pantai Karang Jahe sangat sesuai untuk kegiatan wisata pantai.
\end{abstract}

Kata Kunci: Indek Kesesuaian Wisata, Daya Dukung Kawasan, Pantai Karang Jahe

\section{Analysis of Water Quality Carrying Capacity for Tourism Suitability on Karang Ginger Beach, Rembang}

ABSTRACT : Karang Jahe Beach is one of the new tourist destinations that is starting to become a tourist destination in Central Java. As a new tourist spot, Karang Jahe Beach requires development in an effort to attract tourists to visit. This study aims to examine the suitability and carrying capacity of tourism and examine the potential of the tourist attraction of Karang Jahe Beach, Rembang, Central Java. The study was conducted in January-February 2019. The study used a survey method and the location was chosen using the purposive sampling method. In this study an analysis of the Tourism Suitability Index (IKW) and the Regional Carrying Capacity (DKK) analysis were conducted. Based on observations, the results show that the IKW value for beach recreation at stations 1, 2 and 3 is classified as very suitable (S1) with a value of $88.88 \% ; 91.94 \% ; 84.72 \%$. The carrying capacity of the Region (DDK) is beach recreation activities with an area of $1200 \mathrm{~m} 2$ totaling 96 people / day, swimming activities with an area of $1100 \mathrm{~m} 2$ can accommodate 88 people / day, and play activities with an area of $1000 \mathrm{~m} 2$ can accommodate 80 people / day. Based on the results of IKW and DDK analysis, it can be concluded that Karang Ginger Beach is very suitable for beach tourism activities.

Keywords: Tourism Suitability Index, Regional Capacity, Karang Jahe Beach

\section{PENDAHULUAN}

Wisata pantai merupakan suatu konsep yang mengkombinasikan kepentingan industri kepariwisataan dengan lingkungan. Wisata pada saat sekarang ini menjadi aktivitas yang memberikan kesempatan kepada wisatawan untuk mendapatkan pengalaman mengenai alam dan budaya untuk dipelajari dan memahami betapa pentingnya konservasi keanekaragaman hayati dan budaya lokal. Berdasarkan konsep wisata pantai, kegiatan wisata dengan mengutamakan 
sumberdaya pantai dan budaya masyarakat pantai meliputi rekreasi, olahraga, menikmati pemandangan pantai. Pengembangan industri wisata dijadikan sebagai salah satu strategi yang dipakai oleh pemerintah bahkan swasta untuk mempromosikan wilayah tertentu sebagai daerah tujuan wisata guna meningkatkan perekonomian dan kesempatan kerja (Bahar dan Rahmadi, 2010).

Pantai Karang Jahe adalah salah satu objek wisata pantai yang berada di sebelah utara Desa Punjulharjo yang berada di tengah-tengah jalur utama Kabupaten Rembang - Lasem, lebih tepatnya di Jalan Rembang-Lasem Km 7,5 Desa Punjulharjo Kabupaten Rembang. Prinsip pengembangan wisata adalah menentukan dan mengatur kawasan yang digunakan untuk kegiatan wisata. Daya dukung kawasan mempunyai keterkaitan dengan pengelolaan secara berkelanjutan, artinya pengembangan wisata untuk peningkatan ekonomi hendaknya memperhatikan aspek ekologis dari kawasan pengembangan (Jurado, 2012). Rencana pengelolaan wisata pantai berbasis kesesuaian lahan dan daya dukung diharapkan dapat menjadi solusi dalam mengatasi masalah yang ada. Karena itu, penelitian ini bertujuan untuk mengkaji kesesuaian dan daya dukung kawasan wisata dan mengkaji potensi daya tarik wisata Pantai Karang Jahe, Rembang.

Secara geografis Desa Punjulharjo terletak pada posisi $111^{\circ} 00^{\prime}-111^{\circ} 30^{\prime}$ Bujur Timur (BT) dan $6^{\circ} 30^{\prime}-7^{\circ} 00^{\prime}$ Lintang Selatan (LS), dengan ketinggian kurang lebih $50 \mathrm{~m}$ dari permukaan laut. Luas wilayah Desa Punjulharjo tercatat kurang lebih 393,96 Ha dengan batas - batas wilayah sebelah Utara berbatasan dengan Laut Jawa; Sebelah Timur berbatasan dengan Kecamatan Lasem (Desa Dorokandang dan Desa Gedongmulyo). Sebelah Selatan berbatasan dengan Desa Kasreman, Sebelah Timur berbatasan dengan Desa Tritunggal.

\section{MATERI DAN METODE}

Materi yang dikaji dalam penelitian ini yaitu kondisi fisik dan keadaan alam dari Pantai Karang Jahe, Rembang (Gambar 1). Penelitian dilaksanakan pada bulan Januari-Februari 2019. Lokasi penelitian ditentukan dengan menggunakan metode Purposive random sampling. Penelitian ini menggunakan analisis data primer dan sekunder. Pengukuran parameter lingkungan yang diukur meliputi kedalaman, kecerahan, oksigen terlarut, ketersediaan air tawar, parameter topografi pantai yang meliputi tipe pantai, material dasar perairan, lebar pantai, kemiringan pantai, dan biota berbahaya.

Pengumpulan data sekunder dilakukan melalui studi pustaka dari Badan Meteorologi Klimatologi dan Geofisika Maritim Jawa Tengah dan Pemerintah Desa Punjulharjo Kabupaten Rembang. Studi literatur hasil-hasil penelitian terdahulu di daerah yang sama, serta jurnal-jurnal ilmiah. Data sekunder yang dikumpulkan meliputi kondisi geologi, oseanografi, klimatologi, serta batas administratif, kawasan Pantai Karang Jahe, Rembang.

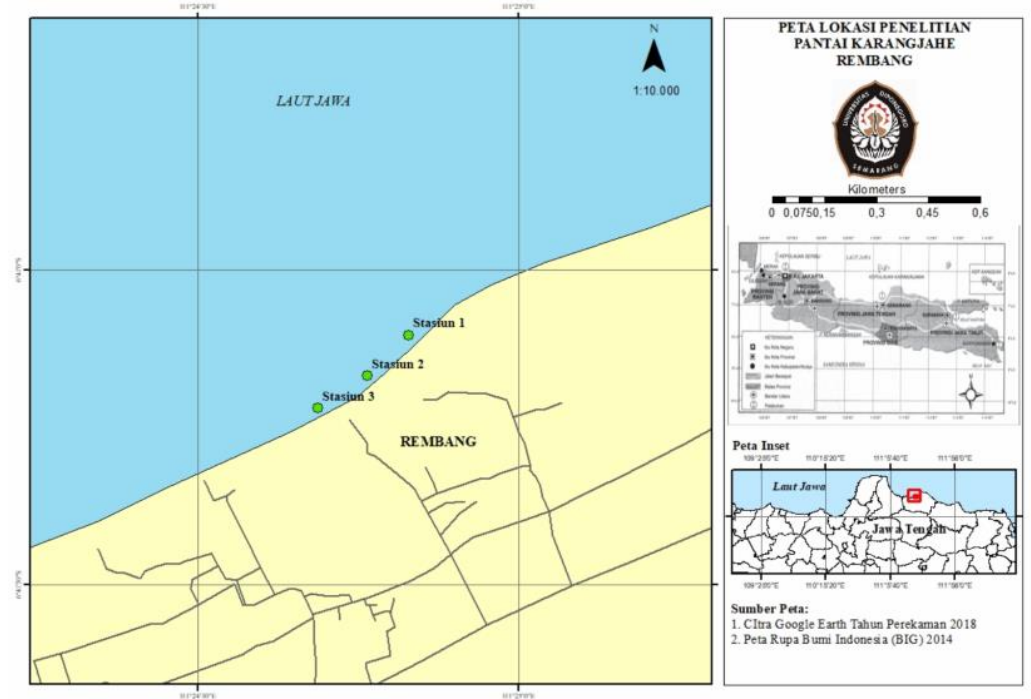

Gambar 1. Peta lokasi penelitian Pantai Karang Jahe, Rembang, Jawa Tengah 


\section{Analisis Data}

Analisa kondisi air laut di Pantai Karang Jahe dilakukan secara langsung di lapangan. Hasil yang diperoleh kemudian dibandingkan dengan Baku Mutu Kualitas Air Laut Untuk Wisata Bahari yang ditetapkan oleh Keputusan Menteri Negara Lingkungan Hidup No.51 Tahun 2004. Analisis Indek Kesesuaian Wisata (IKW) bertujuan untuk mengetahui kesesuaian wisata pada suatu kawasan dalam penggunaan lahan kawasan tersebut. Menurut Yulianda (2007), formulasi untuk menghitung IKW:

$$
\mathrm{IKW}=\sum\left(\frac{\mathrm{Ni}}{\mathrm{Nmax}}\right) \times 100 \%
$$

Keterangan : IKW =: Indeks Kesesuaian Wisata; Ni = Nilai Parameterke-i (bobot $\mathrm{x}$ skor); Nmak = Nilai maksimum dari suatu kategori wisata

\section{Analisis SWOT}

Menurut Rangkuti (2005), analisis SWOT merupakan sarana strategi perencanaan, pengambilan keputusan serta kebijakan dengan memperhatikan situasi dan kondisi lingkungan internal dan eksternal. Analisis SWOT merumuskan strategi dengan cara memaksimalkan kekuatan dan peluang serta meminimalkan kelemahan dan ancaman.

\section{Analisis Daya Dukung Kawasan (DDK)}

Daya dukung sebuah kawasan wisata didefinisikan sebagai tingkat kehadiran wisatawan yang menimbulkan dampak pada masyarakat setempat, lingkungan, dan ekonomi yang masih dapat ditoleransi baik oleh masyarakat maupun wisatawan itu sendiri dan memberikan jaminan keberlangsungan pada masa mendatang (Akliyah and Umar, 2014)

Perhitungan daya dukung kawasan dilakukan untuk mengetahui jumlah maksimum pengunjung yang secara fisik dapat ditampung di kawasan yang tersedia pada waktu tertentu tanpa menimbulkan gangguan pada alam dan manusia. Rumus yang digunakan dalam analisis ini juga mengacu pada Yulianda (2007) sebagai berikut:

$$
\mathrm{DDK}=\mathrm{K} \times \frac{\mathrm{Lp}}{\mathrm{Lt}} \times \frac{\mathrm{Wt}}{\mathrm{Wp}}
$$

Keterangan : DDK = Daya Dukung Kawasan; $K=$ satuan unit area (orang); $L p=$ Luas area $\left(m^{2}\right)$ atau panjang area $(\mathrm{m})$ yang dapat dimanfaatkan; $\mathrm{Lt}$ : Unit area kategori tertentu $\left(\mathrm{m}^{2} / \mathrm{m}\right)$

Pada analisa daya dukung kawasan dilakukan analisa berdasarkan Yulianda (2007), bahwa untuk rekreasi pantai jumlah orang 1 haruslah memiliki area wisata $25 \mathrm{~m}^{2}$, untuk kegiatan berenang 1 orang membutuhkan unit area $25 \mathrm{~m}^{2}$, sedangkan untuk kegiatan bermain 1 orang membutuhkan luasan $25 \mathrm{~m}^{2}$.

Tabel 1. Potensi Ekologis Pengunjung (K) dan luas area kegiatan (Lt)

\begin{tabular}{lccc}
\hline Jenis Kegiatan & Jumlah orang & Unit Area (Lt) & Keterangan \\
\hline Rekreasi Pantai & 1 & $25 \mathrm{~m}^{2}$ & 1 org setiap 5x5 m panjang pantai \\
Berenang & 1 & $25 \mathrm{~m}^{2}$ & 1 org setiap 5x5 m panjang pantai \\
Bermain & 1 & $25 \mathrm{~m}^{2}$ & 1 org setiap 5x5 m panjang pantai \\
\hline
\end{tabular}

Sumber : Yulianda (2007)

\section{HASIL DAN PEMBAHASAN}

Berdasarkan hasil pengukuran diperoleh nilai kisaran $\mathrm{pH}$ perairan Pantai Karang Jahe dari 3 stasiun pengamatan adalah 7,08-7,16. pH tertinggi terdapat pada stasiun 1 dengan nilai 7,16 (Tabel 2)., sedangkan $\mathrm{pH}$ terendah terdapat pada stasiun 2 dan 3 dengan nilai 7,08. Bila dibandingkan dengan nilai pH perairan Pantai Nglambor, Gunungkidul tidak jauh berbeda (Hidayat et al, 2018). Hasil yang terukur menunjukkan bahwa perairan tersebut cocok untuk kegiatan wisata pantai karena masih berada pada kisaran $\mathrm{pH}$ normal yang ditetapkan oleh Menteri Lingkungan Hidup (2004) yaitu 7-8,5. Suhu perairan Pantai Karang Jahe memiliki nilai yang terukur 26,41$26,45^{\circ} \mathrm{C}$ (Tabel 2). Nilai suhu tertinggi terdapat pada stasiun 1 dengan nilai $26,45^{\circ} \mathrm{C}$, sedangkan 
yang terendah terdapat pada stasiun 2 dengan nilai $26,41^{\circ} \mathrm{C}$. Kisaran nilai suhu sesuai dengan suhu di perairan Pantami Bandengan, Jepara $\left(27,50-27,75^{\circ} \mathrm{C}\right)($ Utomo, 2011). Salinitas perairan Pantai Karang Jahe memiliki nilai yang terukur 30,58-31,58\%. Nilai salinitas tertinggi terdapat pada stasiun 2 dan 3 dengan nilai 31,58\%, sedangkan yang terendah terdapat pada stasiun 1 dengan nilai 30,58\%o, dibandingkan dengan salinitas perairan Pantai Bandengan, Jepara dengan nilai 31,33-32,08\%o tidak jauh berbeda (Utomo, 2011, Juliana et al, 2013).

Kecerahan perairan Pantai Karang Jahe memiliki nilai yang terukur 0,25-0,27 meter (Tabel 2). Nilai kecerahan tertinggi terdapat pada stasiun 3 dengan nilai 0,27 meter, sedangkan yang terendah terdapat pada stasiun 1 dengan nilai 0,25 meter. Kecerahan perairan $<6$ m didapatkan berdasarkan dengan pertimbangan dan pengambilan dari titik stasiun dibandingkan dengan Kecerahan perairan Pantai Bandengan, Jepara dengan nilai 1-2 m tidak jauh berbeda (Utomo, 2011). Bila nilai kecerahan dibandingkan dengan kriteria Yulianda (2007), maka perairan Karang Jahe memiliki niai yang kurang dari 10m, sedangkan berdasarkan Yulianda (2007), bahwa nilai kecerahan perairan untuk kategori wisata pantai seharusnya memiliki kecerahan perairan yaitu > 10 m. (Yulianda, 2007).

Sebaran DO (Oksigen terlarut) di perairan Pantai Karang Jahe memiliki nilai berkisar antara $10,06-10,17 \mathrm{mg} / \mathrm{l}$. Nilai DO tertinggi terdapat pada stasiun 2 dengan nilai $10,17 \mathrm{mg} / \mathrm{l}$, sedangkan nilai terendah terdapat pada stasiun 1 dengan nilai $10,06 \mathrm{mg} / \mathrm{l}$, dibandingkan dengan $\mathrm{DO}$ perairan Pantai Bandengan, Jepara dengan nilai 13,07 mg/l tidak jauh berbeda (Utomo, 2011).

Hasil penelitian dari stasiun 1 menunjukkan bahwa Pantai Karang Jahe merupakan pantai berpasir putih kecoklatan. Stasiun 1 memiliki lebar pantai 73,27m. Kemiringan pantai di stasiun 1 adalah $3,12^{\circ}$. Material pantai pada stasiun 1 berupa pasir. Kecepatan arus pada stasiun 1 senilai $0,05 \mathrm{~m} / \mathrm{s}$. Penutupan lahan pantai berupa Cemara laut. Di Pantai tersebut tidak ditemukan adanya biota berbahaya. Ketersediaan air tawar kurang dari 0,5 km . Jarak dari stasiun 1 menuju sumber air tawar terdekat sejauh 70 meter (Tabel 3). Hasil pengukuran parameter kondisi fisik pantai stasiun 2 menunjukkan bahwa Pantai Karang Jahe merupakan pantai berpasir putih kecoklatan. Stasiun 2 memiliki lebar pantai $74,15 \mathrm{~m}$. Kemiringan pantai di stasiun 2 adalah 3,24${ }^{\circ}$. Material pantai pada stasiun 2 berupa pasir. Kecepatan arus pada stasiun 2 senilai $0,05 \mathrm{~m} / \mathrm{s}$. Penutupan lahan pantai berupa Cemara laut. Tidak ditemukan adanya biota berbahaya. Ketersediaan air tawar kurang dari $0,5 \mathrm{~km}$. Jarak dari stasiun 2 menuju sumber air tawar terdekat sejauh $55 \mathrm{~m}$ (Tabel 3).

Hasil pengukuran parameter kondisi fisik pada stasiun 3 menunjukkan bahwa Pantai Karang Jahe merupakan pantai berpasir putih kecoklatan. Stasiun 3 memiliki lebar pantai 75,3m. Kemiringan pantai di stasiun 3 adalah $3,26^{\circ}$. Bila dibandingkan dengan kawasan wisata pantai Botutonu (Wunani et al., 2013), makadapat disimpulkan bahwa kemiringan pantai Karang Jahe tergolong landai (Panjaitan et al., 2012) Sehingga diperoleh hasil pengukuran kemiringan pantai yang menunjukkan bahwa Pantai Botutonuo memiliki dua jenis topografi pantai, yaitu pada Stasiun 1 dan Stasiun 2 memiliki topografi pantai yang landai yaitu $13,2^{\circ}$ dan $11,3^{\circ}$, sedangkan Stasiun 3 yaitu memiliki topografi pantai yang datar dengan kemiringan $9,9^{\circ}$. Hal ini menunjukkan bahwa kemiringan Pantai B

Material pantai pada stasiun 3 berupa pasir. Kecepatan arus pada stasiun 3 senilai $0,05 \mathrm{~m} / \mathrm{s}$. Penutupan lahan pantai berupa Cemara laut. Tidak ditemukan adanya biota berbahaya. Ketersediaan air tawar kurang dari 0,5 km, sumber air tawar terdekat sejauh $105 \mathrm{~m}$ (Tabel 3).

Berdasarkan data yang diperoleh dari BMKG Maritim Semarang diketahui bahwa suhu rata rata perairan di Rembang $29,3^{\circ} \mathrm{C}$. Suhu terhangat pada bulan Oktober yaitu $30,7^{\circ} \mathrm{C}$ dan suhu terdingin pada bulan Juli yaitu $27,8^{\circ} \mathrm{C}$. Kecepatan angin rata - rata tahunan di Rembang adalah 8,75 knot. Rata - rata kecepatan arus tahunan di Pantai Karang Jahe Rembang adalah 0,145 m/s. Maksimum tinggi gelombang rata - rata tahunan adalah 0,79 m dengan gelombang tertinggi $1,0 \mathrm{~m}$ pada bulan Januari.

Pasang surut di perairan Pantai Karang Jahe, Rembang terukur dengan nilai rata-rata pasang tertinggi tahunan sebesar $1,24 \mathrm{~m}$. Surut terendah rata-rata tahunan sebesar 0,48 $\mathrm{m}$. Sedangkan nilai rata-rata pasang surut tahunan sebesar $0,87 \mathrm{~m}$. Surut terendah pada perairan Pantai Karang Jahe terjadi pada bulan Maret, Juli, dan Desember sebesar 0,4 meter, pasang tertinggi terjadi pada bulan April dan Mei yaitu sebesar 1,51 m dan 1,52 m. 
Tabel 2. Nilai rata-rata hasil pengukuran kondisi perairan Pantai Karang Jahe, Rembang

\begin{tabular}{ccccc}
\hline Parameter & Satuan & Stasiun 1 & Stasiun 2 & Stasiun 3 \\
\hline pH & & 7,16 & 7,08 & 7,08 \\
Suhu & $\left({ }^{\circ} \mathrm{C}\right)$ & 26,45 & 26,41 & 26,43 \\
Salinitas & $(\%)$ & 30,58 & 31,58 & 31,58 \\
Kecerahan & $(\mathrm{m})$ & 0,25 & 0,26 & 0,27 \\
DO & $(\mathrm{mg} / \mathrm{l})$ & 10,06 & 10,17 & 10,13 \\
Bau & & Tidak berbau & Tidak berbau & Tidak berbau \\
Sampah & & Tidak ada & Tidak ada & Tidak ada \\
\hline
\end{tabular}

Tabel 3. Nilai rata-rata parameter kondisi perairan Pantai Karang Jahe Rembang

\begin{tabular}{lclll}
\hline \multicolumn{1}{c}{ Parameter } & Satuan & \multicolumn{1}{c}{ Stasiun 1 } & \multicolumn{1}{c}{ Stasiun 2 } & \multicolumn{1}{c}{ Stasiun 3 } \\
\hline Tipe pantai & - & Landai & Landai & Landai \\
Lebar pantai & $\mathrm{m}$ & 73,27 & 74,15 & 75,3 \\
Kemiringan pantai & 0 & 3,12 & 3,24 & 3,26 \\
$\begin{array}{l}\text { Material pantai } \\
\text { Kecepatan arus }\end{array}$ & - & Pasir & Pasir & Pasir \\
$\begin{array}{l}\text { Penutupan lahan } \\
\text { pantai }\end{array}$ & $\mathrm{cm} / \mathrm{s}$ & 5 & 5 & 5 \\
$\begin{array}{l}\text { Biota berbahaya } \\
\text { Ketersediaan air }\end{array}$ & - & Cemara laut & Cemara laut & Cemara laut \\
$\begin{array}{l}\text { tawar (jarak dari } \\
\text { stasiun 1) }\end{array}$ & $\mathrm{m}$ & Tidak ada & Tidak ada & Tidak ada \\
$\begin{array}{l}\text { Ukuran butir } \\
\text { sedimen }\end{array}$ & $\mathrm{mm}$ & $0,25-0,074$ & $0,841-0,074$ & $0,841-0,074$ \\
\hline
\end{tabular}

\section{Sarana dan Prasarana}

Perjalanan menuju Pantai Karang Jahe dapat diakses dengan menggunakan kendaraan pribadi maupun kendaraan umum. Jaraknya kurang lebih 800 meter dari jalan raya nasional dan ini memudahkan akses kendaraan umum maupun kendaraan pribadi. Sarana prasarana pendukung sebagai fasilitas pendukung yakni aksesbilitas. Akses jalan menuju Pantai Karang Jahe, Rembang sangat mudah karena kondisi jalan menuju lokasi sudah beraspal baik. Meskipun ada beberapa yang belum diaspal penuh. Lokasinya pun tidak jauh dari pusat kota Rembang, hanya sekitar $7,5 \mathrm{~km}$. Sarana prasarana wisata yang tersedia di Pantai Karang Jahe cukup memadai yaitu loket tiket, tempat parkir, WC atau toilet kamar mandi, tempat ibadah tempat duduk, tempat pembuangan sampah, kios atau warung makan, penginapan, dan tempat pertemuan (Tabel 4).

Berdasarkan pengamatan, di tempat wisata tersebut terdapat kamar mandi $/$ WC berjumlah 45 dengan kondisi baik (Tabel 4). Pada Pantai Karang Jahe terdapat 150 tempat sampah dan ini membuat kawasan wisata tersebut menjadi bersih. Disamping itu terpat pulah 90 kios dan warung makanan dengan kondisi yang bersih dengan membuat para wisatawan merasa nyaman. (Tabel 4). Dalam rangka mendukung wisatawan yang ingin beribadah, di lokasi Pantai Karang Jahe tersedia 1 buah mesjid dengan kondisi yang bersih dan baik, demikian juga terdapat 1 mushola dengan kondisi cukup baik (Tabel 4).

\section{Persentase Indeks Kesesuaian Wisata}

Perhitungan persentase nilai indeks kesesuaian wisata (IKW) di Pantai Karang Jahe Kabupaten Rembang dilakukan dengan mempertimbangkan semua parameter terkait. Hasil 
perhitungan persentase indeks kesesuaian wisata pada tiga stasiun pengamatan di Pantai Karang Jahe menunjukkan angka diatas $80 \%$. Nilai IKW lebih dari $80 \%$ ini menunjukkan bahwa Pantai Karang Jahe layak sebagai wisata pantai karena termasuk kategori S1 (sangat sesuai) (Tabel 5). Berdasarkan hasil perhitungan nilai indek kesesuaian wisata menunjukkan bahwa Pantai Karang Jahe Kabupaten Rembang termasuk kategori Sangat Sesuai (S1) (Tabel 5). Hal ini sesuai dengan hasil penelitian Winani et al (2013) bahwa nilai indek kesesuaian wisata lebih besar dari 80\%.

\section{Analisis SWOT}

Faktor strategis internal dalam pengelolaan dan pengembangan wisata pantai di Pantai Karang Jahe, Rembang terdiri dari kekuatan dan kelemahan kegiatan wisata. Faktor Kekuatan meliputi tinggi gelombang lebih rendah dibandingkan pantai utara yang lain; Kawasan yang tergolong baru untuk kegiatan wisata; Memiliki panorama yang indah; Kesadaran masyarakat sekitar akan kebersihan lingkungan. Hal ini dapat dibandingkan dengan Faktor kekuatan Pantai Situbondo meliputi adanya perahu layar sebagai ciri khas; Dapat melihat terumbu karang; Aman untuk berenang; Pemandangan pantai dengan ombak tenang; Terdapat pepohonan (teduh); Lokasi strategis (berada pada jalur pantura). Faktor kekuatan pada Pantai Karang Jahe dan Pantai Situbondo jelas berbeda, hal ini merupakan strategi jangka panjang serta adanya karakteristik pantai yang berbeda.

Faktor Kelemahan meliputi Lahan parkir rusak dan Kurangnya penataan lahan usaha milik masyarakat setempat. Hal ini dapat dibandingkan dengan Faktor kekuatan Pantai Situbondo meliputi belum adanya inovasi wahana; Fasilitas untuk melihat terumbu karang minim; Belum adanya batas zona aman untuk berenang; Sampah berserakan. Faktor kelemahan Pantai Karang Jahe dan Pantai Siubondo jelas berbeda, hal ini merupakan faktor yang dapat diatasi dengan adanya strategi kekuatan-kelemahan.

\section{Analisis Daya Dukung Kawasan}

Potensi ekologis pengunjung per satuan unit area dan unit area untuk kategori tertentu dan waktu yang dapat digunakan untuk setiap kegiatan wisata dapat dilihat pada Tabel 6. Hasil perhitungan total daya dukung di kawasan Pantai Karang Jahe, Rembang adalah 264 orang/hari (Tabel 7). Sehingga dapat disimpulkan bahwa pantai ini dapat menampung seluruh kegiatan wisata yang dilakukan para pengunjung dengan baik tanpa melebihi daya dukung kawasan sehingga pantai ini kelestariannya tetap terjaga.

Berdasarkan analisa daya dukung kawasan bahwa di Pantai Karang Jahe Rembang diperoleh hasil bahwa untuk rekreasi pantai diperoleh daya dukung kawasan sebesar 96 orang/hari, untuk kegiatan berenang yaitu sebesar 88 orang/hari dan unuk kegiatan bermain dengan nilai sebesar 80 orang/ hari. Hal ini juga sesuai dengan Wunani et al. (2013) bahwa di Pantai Botutonuo, Kec. Kabila Bone, Kab. Bone Bolango daya dukung kawasan untuk aktivitas berenang sebesar 81 orang / hari.

Tabel 4. Sarana dan Prasarana di Pantai Karang Jahe Kabupaten Rembang

\begin{tabular}{llcl}
\hline No & Jenis Sarana Prasarana & Fisik (Unit) & \multicolumn{1}{c}{ Keterangan } \\
\hline 1 & Area Parkir & 2 & Parkir motor dan parkir mobil \\
2 & Kamar mandi/WC & 45 & Kondisi baik, lengkap \\
3 & Tempat lbadah & 2 & Masjid : kondisi sangat baik, \\
4 & Penginapan & 3 & Mushola : kondisi cukup \\
5 & Kios/Warung makan & 90 & Dikelola/ Milik warga sekitar \\
6 & Tempat sampah & 150 & 100 unit tong, 50 unit anyaman \\
7 & Tempat pertemuan & 1 & Kondisi sangat baik \\
\hline
\end{tabular}


Tabel 5. Hasil persentase nilai IKW pada 3 stasiun di Pantai Karang Jahe Kabupaten Rembang

\begin{tabular}{cccl}
\hline Stasiun & $\begin{array}{c}\text { Total } \\
\text { (bobot } x \text { skor) }\end{array}$ & $\begin{array}{c}\text { IKW } \\
(\%)\end{array}$ & \multicolumn{1}{c}{ Kelas kesesuaian } \\
\hline 1 & 64 & 88,88 & S1 (Sangat sesuai) \\
2 & 69 & 91,94 & S1 (Sangat sesuai) \\
3 & 61 & 84,72 & S1 (Sangat sesuai) \\
\hline
\end{tabular}

Tabel 6. Waktu yang dibutuhkan untuk setiap kegiatan wisata

\begin{tabular}{llcc}
\hline No & Kegiatan & $\begin{array}{c}\text { Waktu yang dibutuhkan Wp } \\
(\text { jam })\end{array}$ & Total waktu 1 hari Wt (jam) \\
\hline 1 & Rekreasi pantai & 3 & 6 \\
2 & Berenang & 2 & 4 \\
3 & Bermain & 3 & 6 \\
\hline
\end{tabular}

Tabel 7. Daya Dukung Kawasan

\begin{tabular}{llc}
\hline No & Kegiatan & Daya Dukung Kawasan (Orang/Hari) \\
\hline 1 & Rekreasi pantai & 96 \\
2 & Berenang & 88 \\
3 & Bermain & 80 \\
\hline & JUMLAH & 264 \\
\hline
\end{tabular}

\section{KESIMPULAN}

Pantai Karang Jahe, Rembang memiliki kesesuaian lahan yang tergolong sangat sesuai untuk kegiatan rekreasi pantai, berenang, dan bermain dengan Indeks Kesesuaian Wisata menunjukkan lebih dari 80\% yakni 88,88\%; 91,94\%; dan 84,72\% di 3 stasiun. Faktor yang sangat mendukung yaitu lahan terbuka yang luas, kondisi fisik pantai yang cukup baik, dan sarana prasarana cukup memadai. Tingkat daya dukung kawasan Pantai Karang Jahe adalah 96 orang per hari untuk rekreasi pantai, 88 orang per hari untuk aktivitas berenang, dan 80 orang per hari untuk aktivitas bermain. Pengembangan daya tarik wisata kawasan Pantai Karang Jahe terdapat sembilan kriteria pengelolaan kawasan wisata Pantai Karang Jahe yang sesuai dengan potensi, kekuatan, kelemahan serta ancaman kawasan tersebut.

\section{DAFTAR PUSTAKA}

Akliyah, L.S. \& Umar, M.Z. 2014. Analisis daya dukung kawasan wisata panjtai Sebanjar Kab. Alor dalam mendukung pariwisata yang berkelanjutan. Jurnal Perencanaan Wilayah dan Kota,13(2):1-8

Bahar, A. \& Tambaru, R. 2010. Analisis Kesesuaian dan Daya Dukung Kawasan Wisata Bahari di Kabupaten Polewali Mandar. Fakultas IImu Kelautan dan Perikanan UNHAS.

Panjaitan, R.A., Iskandar \& Alisyahbana, S. 2012. Hubungan Perubahan Garis Pantai Terhadap Habitat Bertelur Penyu Hijau (Chelonia mydas) di Pantai Pangumbahan Ujung Genteng Kabupaten Suka Bumi. Jurnal Perikanan dan Kelautan, 3(3):311-320

Rangkuti, F. 2005. Analisis SWOT : Teknik Membedah Kasus Bisnis. Gramedia. Jakarta.

Utomo, B. 2011. Studi Kelayakan Fisik Pengembangan Pariwisata di Pantai Bandengan, Kabupaten Jepara, Jawa Tengah. FPIK, Universitas Diponegoro. Semarang.

Wunani, D., Nursinar, S. \& Kasim, F. 2013. Kesesuaian Lahan dan Daya Dukung Kawasan Wisata Pantai Botutonuo, Kecamatan Kabila Bone, Kabupaten Bone Bolango. Jurnal IImiah Perikanan dan Kelautan, 1(2):89-94.

Yulianda, F. 2007. Ekowisata bahari sebagai alternatif pemanfaatan sumberdaya pesisir berbasis konservasi. Makalah Seminar Sains pada Departemen Manajemen Sumberdaya Perairan. Fakultas Perikanan dan IImu Kelautan IPB. Bogor. 